\title{
Evaluation of Water Quality on TNF- $\alpha$ and IL- 1 Immune Genes in Oreochromis Niloticus Fish at El Manzala Lake in Egypt
}

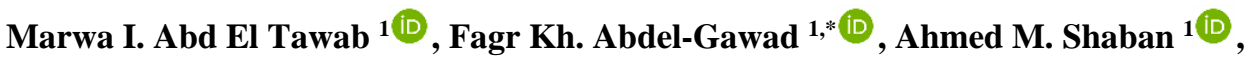 \\ Samah M. Bassem $^{1}$ (D), Giulia Guerriero ${ }^{2}$ (D) , Hanan A. Goda $^{3}$ (D), Aziz M. Higazy $^{3}$ (D) \\ 1 Centre of Research and Applied Studies for Climate Change and Sustainable Development, Water Pollution Research \\ Department, CEAS, National Research Centre, Egypt \\ 2 Biology Department of, University of Napoli Federico II, Italy \\ 3 Agricultural Microbiology Department., Faculty of Agriculture, Cairo University, Giza, Egypt \\ * Correspondence: fagrabdlgawad@gmail.com;
}

Scopus Author ID 16232444500

Received: 28.06.2020; Revised: 18.08.2020; Accepted: 20.08.2020; Published: 25.08.2020

\begin{abstract}
Lake Manzala is known to be from the most significant sources of inexpensive different fish species for human consumption in Egypt. The Lake receives pollution from various sources; domestic wastewater, industrial wastewater, and agricultural drainage directly without any treatments, which lead to many environmental disorders. The following research was conducted for lake water quality evaluation and how it impacts the expression of Tumor necrosis factor- $\alpha$ (TNF- $\alpha$ ) and Interleukin-1 (IL- 1) immune genes. Sampling was done seasonally from October 2015 to September 2016, where water and fish samples were collected from 4 locations in El Manzala Lake after mixing with Bahr El Baqr drain (sampling points were $4 \mathrm{~km}$ apart from each other). Average values of dissolved oxygen,

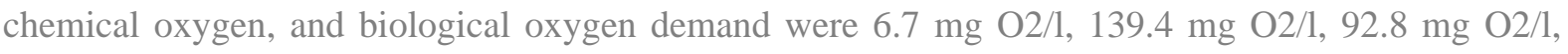
respectively. For the Nitrogen group, the average concentration of ammonia, nitrite, and nitrate was $0.7 \mathrm{mg} / 1,0.38 \mathrm{mg} / 1$, and $0.38 \mathrm{mg} / 1$, respectively. The average records of total bacterial count and total and fecal coliform suggesting high loads of contaminants, particularly in sampling sites close to Bahr El Baqr drain. The relative occurrence of cyanobacteria in water samples was influenced by increasing lake water temperature. The expression of the immune genes for TNF- $\alpha$ and IL- 1 in Nile Tilapia fish liver was confirmed by RT-PCR. The results showed up-regulation of these genes in the liver of Nile Tilapia fish, especially in warm seasons (summer, late summer). TNF- $\alpha$ and IL- 1 level in Nile Tilapia fish could be used as early diagnostic indicators to different environmental events and also are helpful and reliable bioindicators in estimating pollutants of the aquatic environment. High levels of pollution in El Manzala Lake were recorded in this study that may proceed with health risks to a human. Therefore, the Lake needs proper policies to protect and preserve its ecological integrity and biodiversity.
\end{abstract}

Keywords: El Manzala Lake; water pollution; immune genes (TNF- $\alpha$ and IL-1 gene) and Nile Tilapia (Oreochromis niloticus).

(C) 2020 by the authors. This article is an open-access article distributed under the terms and conditions of the Creative Commons Attribution (CC BY) license (https://creativecommons.org/licenses/by/4.0/).

\section{Introduction}

El Manzala Lake is a brackish shallow water lake and considered to be the largest coastal Lake along the Nile Delta. It is located between the Damietta River Nile branch and the Suez Canal with a length of $50 \mathrm{~km}$ along the coast of the Mediterranean Sea [1]. From the northern side, the Lake connects to the Mediterranean sea through EL Gamil Canal, while from 
the eastern side, the Lake is connected with Suez Canal through the El Qabouty Canal [2]. The average fish production of El Manzala Lake is 60,000 tons annually, where tilapia represents more than $65 \%$ of fish species in the Lake. Despite that, the Lake is suffering from a significant water pollution problem represented in wastewater effluent discharge in the Lake and land reclamation [3]. The Lake was exhibited to many threats during the last six decades due to agricultural drainage, municipal and industrial wastewater affecting lake biodiversity greatly [4]. A sum of $3.7 \mathrm{~km}^{3}$ of freshwater (mainly from agriculture drainage) flow yearly to the Lake from four main drains: Bahr El Baqar drain, Al Sarw, Freskur, and Al Hadous drain. The Bahr El Bakr drain is at the top of the list of drains that discharge their wastewater to the Lake, [5] and one of the most polluted drains [6]. The decline of water quality conditions such as temperature, hypoxia will, in turn, induce the immune system of fish and result in fish susceptibility to pathogenic infection and consequently affecting the lake fish yield [7, 8, 9]. Cytokine releasing is one of the most relevant tools for the investigation of immune system toxicity [7]. Cytokine group is immune modulators involved in chemotaxis, complement activation, and pathogen killing and opsonization in the phagocytosis process $[10,11]$. One of the cytokines is Interleukin (IL) was secreted by many cells and affecting a variety of cells that is responsible for expression in addition to regulation of organism's immune response. The Tumor Necrosis Factor (TNF- $\alpha$ ) is one of the smallest proteins produced by macrophages, which had a prim role in the organism's innate immunity $[12,13]$. Such inflammatory agents impact the synthesis of many other immune-related pathways markers and also enzyme efficiency. It was proved previously that both IL-1 $\beta$ and $\alpha$ are able to initiate inflammation by adjusting the expression of the other cytokines [14]. To reveal the effect of water pollution on El Manzala Lake, cytokines (TNF- $\alpha$ and IL-1genes) levels were determined. Therefore, the aim of the present work is to assess the impact of water pollution on the aquatic life of El Manzala Lake through studying the physicochemical and microbiological quality of the southern side of the Lake. Also, examining the changes of TNF- $\alpha$ and IL-1genes of Nile Tilapia fish (Oreochromis niloticus) was carried out by Semi-quantitative RT-PCR.

\section{Materials and Methods}

\subsection{Sampling sites.}

Water samples were collected at the southern side of El Manzala Lake after mixing with Bahr El Baqr drain, at four sampling sites, Site 1: after $2 \mathrm{~km}$ from Bahr El Baqr drain, Site 2: after $4 \mathrm{~km}$ from Bahr El Baqr drain, Site 3: after $8 \mathrm{~km}$ from Bahr El Baqr drain and Site 4: after $12 \mathrm{~km}$ from Bahr El Baqr drain (figure 1).

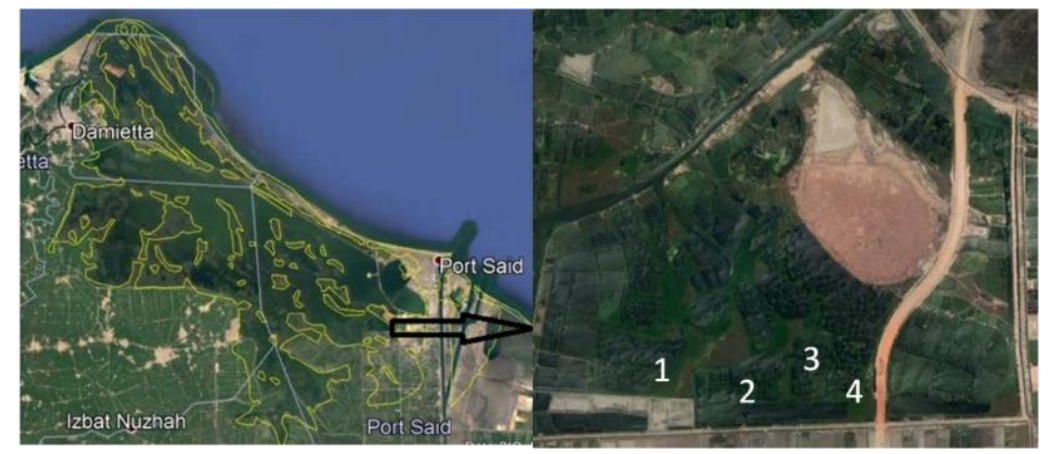

Figure. 1. Map of El Manzala Lake showing sampling locations. 


\subsection{Water sampling.}

Water samples were taken seasonally (three samples were taken from each site) during October 2015-September 2016. Surface water samples were collected in a 1-literplastic bottle for the physicochemical analysis and 1-literglass bottle for the microbiological analysis [15]. The samples were transported within 3 hours in an icebox to biotechnology and biodiversity conservation laboratory, Centre of Excellence for Advanced Sciences, National Research Centre.

\subsection{Fish samples.}

During the period of October 2015-September 2016, Nile Tilapia fish (Oreochromis niloticus) were collected seasonally from Manzala Lake after mixing with Bahr El Baqr (from site 2). In addition, Control fish samples of Nile Tilapia were collected from the National Research Centre farm at EL-Noubarya, Egypt. Fish samples were transported to biotechnology and biodiversity conservation laboratory, Centre of Excellence for Advanced Sciences, National Research Centre in an icebox for the gene expression analysis.

\subsection{Physicochemical analysis of water.}

Temperature and $\mathrm{pH}$ were measured in the field using a portable $\mathrm{pH}$ meter (Model Jenway). Dissolved oxygen (DO) was determined in the field using (Oxygen meter model). For the analysis of biological oxygen demand (BOD), chemical oxygen demand (COD), total dissolved solids (TDS), salinity, ammonia $\left(\mathrm{NH}_{4}-\mathrm{N}\right)$ nitrogen, nitrite nitrogen $\left(\mathrm{NO}_{2}-\mathrm{N}\right)$ and nitrate-nitrogen $\left(\mathrm{NO}_{3}-\mathrm{N}\right)$, they were done using the standard method of water analysis [15].

\subsection{Microbiological examination of water samples.}

Ten $\mathrm{ml}$ of each water sample was serially diluted in sterile saline water $(\mathrm{NaCl} 0.85 \%)$ to the appropriate dilutions for the microbiological analysis. The pour-plate technique was applied to enumerate total bacterial count (TBC) using plate count agar medium (tryptone glucose yeast extract agar), [16], and Staphylococcus aureus using Vogel Johnson agar [17]. The same technique was used to determine the count of spore-forming bacteria (SFB), but all dilution tubes were pasteurized at $80^{\circ} \mathrm{C} / 15 \mathrm{~min}$., followed by sudden cooling before the plating step. The total and fecal coliforms were determined using the Most Probable Number (MPN) method (FDA/BAM 2002, updated 2013). The medium used for the possible test was lauryl tryptose broth. Brilliant green lactose bile (BGLB) broth and EC broth were used for the confirmation test of total and fecal coliforms, respectively. Also, the relative occurrence of cyanobacteria was tested using enrichment culture technique and BG-11 broth [18].

\subsection{Gene expression of fish.}

2.6.1. Fish sample preparation.

Tilapia fish samples were collected from El Manzala Lake, and a control fish were collected from the National Research center farm station, ELNoubariya Province, Alexandria Desert Road, EL Behera Governorate Egypt. In the laboratory, Liver organs were dissected aseptically. Afterward, liver samples were preserved at $-80^{\circ} \mathrm{C}$ until further analysis. 
2.6.2. RNA extraction.

Total RNA was isolated from 30 to $50 \mu \mathrm{g}$ of liver tissue using BioFlux DNA/RNA extraction, purification kit from Bioer Technology Co., Ltd, China, following the manufacturer's protocol.

\subsubsection{Reverse transcription.}

The complete Poly(A)+ RNA isolated fish samples were reversely transcribed into cDNA in a total volume of $20 \mu \mathrm{l}$ using PCR/RT-PCR Kit, Bioer, China, and following the manufacturer's protocol. The composition of the reaction mixture, termed as master mix (MM), consisted of $50 \mathrm{mM} \mathrm{MgCl}_{2}$, 10x reverse transcription (RT) buffer (50 mM KCl; $10 \mathrm{mM}$ Tris$\mathrm{HCl}$; pH 8.3), $10 \mathrm{mM}$ of each $\mathrm{dNTP}$, and $50 \mu \mathrm{M}$ of oligo (dT) primer. The RT reaction was carried out at $25^{\circ} \mathrm{C}$ for $10 \mathrm{~min}$, followed by $1 \mathrm{~h}$ at $42^{\circ} \mathrm{C}$, and finished with denaturation step at $99^{\circ} \mathrm{C}$ for $5 \mathrm{~min}$. Afterward, the reaction tubes containing RT preparations were flash-cooled in $-80{ }^{\circ} \mathrm{C}$ until being used for DNA amplification through polymerase chain reaction (PCR) [19].

\subsubsection{Polymerase chain reaction (PCR).}

The first-strand cDNA from different fish samples was used as templates for RT-PCR with a pair of specific primers. The sequences of specific primer and product sizes are listed in Table 1.

$\beta$-Actin was used as a housekeeping gene for normalizing mRNA levels of the target genes. The reaction mixture for RT-PCR was consisted of $10 \mathrm{mM}$ dNTP's, $50 \mathrm{mM} \mathrm{MgCl2}, 10 \mathrm{x}$

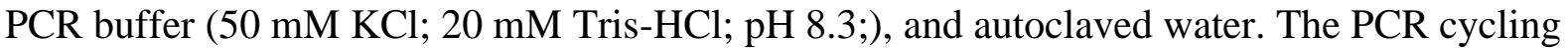
parameters were one cycle of $94^{\circ} \mathrm{C}$ for $5 \mathrm{~min}, 40$ cycles of $94^{\circ} \mathrm{C}$ for $10 \mathrm{~s}, 55^{\circ} \mathrm{C}$ for $30 \mathrm{~s}, 72^{\circ} \mathrm{C}$ for $40 \mathrm{~s}$, and a final cycle of $72^{\circ} \mathrm{C}$ for $7 \mathrm{~min}$. The PCR products were then loaded onto $2.0 \%$ agarose gel, with PCR products derived from $\beta$-actin of the different fish samples [20].

\begin{tabular}{|c|c|c|c|}
\hline gene & Primer sequence & $\begin{array}{l}\text { PCR product } \\
\text { Size(bp) }\end{array}$ & Reference \\
\hline$\beta$-Actin & $\begin{array}{l}\text { F:TGGGGCAGTATGGCTTGTATG } \\
\text { R: CTCTGGCACCCTAATCACCTCT }\end{array}$ & 165 & [21] \\
\hline TNF- $\alpha$ & $\begin{array}{l}\text { F:GCTGGAGGCCAATAAAATCA. } \\
\text { R: CCTTCGTCAGTCTCCAGCTC. }\end{array}$ & 339 & [19] \\
\hline IL- 1 & $\begin{array}{l}\text { F:TGCTGAGCACAGAATTCCAG. } \\
\text { R: GCTGTGGAGAAGAACCAAGC. }\end{array}$ & 371 & [19] \\
\hline
\end{tabular}

\subsection{Statistical analysis.}

Data were analyzed using a one-way analysis of variance (one-way ANOVA) to check the significant differences between the studied physicochemical and microbiological parameters at different pollution sites where the comparison between means was determined by Dunken $(\mathrm{P} \leq 0.05)$. 


\section{Results and Discussion}

\subsection{Physicochemical analysis of El Manzala Lake water.}

\subsubsection{Physicochemical analysis of El Manzala Lake water sample.}

Physicochemical analysis of water in the study are presented in Table 2 . The results of $\mathrm{pH}$ in El Manzala Lake ranged from 7.2-8.2 during the period of study. The results showed that the concentration of total dissolved solids (TDS) ranged from a minimum value of $23.6 \mathrm{~g} / \mathrm{l}$ to a maximum value of $39 \mathrm{~g} / \mathrm{l}$ with an average value of $28.7 \mathrm{~g} / \mathrm{l}$ The corresponding values of the salinity were $2 \mathrm{~g} / \mathrm{l}, 3.4 \mathrm{~g} / \mathrm{l}$ and $2.6 \mathrm{~g} / \mathrm{l}$ for the minimum, maximum and average value, respectively. For the DO, COD and $\mathrm{BOD}$, the results revealed that the average values were $6.7 \mathrm{mg} \mathrm{O}_{2} / 1$ for the DO, $139.4 \mathrm{mg} \mathrm{O} / /$ for the COD and $92.8 \mathrm{mg} \mathrm{O}_{2} / 1$ for the BOD. In this study, the ammonia concentrations ranged between 0.0 to $2.6 \mathrm{mg} \mathrm{N} / 1$ with $0.70 \mathrm{mg} \mathrm{N} / 1$ as an average value. The nitrite concentrations recorded maximum value of $1.6 \mathrm{mg} \mathrm{N} / \mathrm{l}$ and an average value of $0.38 \mathrm{mg} \mathrm{N} / 1$. The nitrate concentrations recorded maximum value of $1.6 \mathrm{mg} \mathrm{N} / \mathrm{l}$ and an average value of $0.38 \mathrm{mg} \mathrm{N} / \mathrm{l}$ and. For total phosphorus, the results showed an average value of $0.40 \mathrm{mg} / \mathrm{l}$ and a maximum value of $0.9 \mathrm{mg} / \mathrm{l}$.

In the present study, The values of total dissolved solids are higher than the values measured by [2]. The values of salinity are in the same accordance with [9]. The variation of results is due to the Lake receiving large quantities of different drainage effluent with high nutrient concentration and low level of salinity, as reported by [1]. The variation in the physicochemical parameters results could be attributed to the variation in the sampling sites, which is influenced by the distance from Bahr El Baqr drain inlet and each sampling site location. The results of DO and BOD are in accordance with [2], which is indicative of the presence of non-biodegradable pollution sources [22]. The results of ammonia and nitrite are higher than the permissible limits of the Egyptian legislation of the national law 48/1982 and in accordance with [1]. The presence of ammonia and nitrite; they are considered to be toxic to aquatic life; it is attributed to the presence of fecal coliform bacteria coming with drains entering El Mazala Lake [22]. High values of both COD and NO3 may be referred to as microbial pollution [23]. For the TP results are lower than the permissible limits of the Egyptian legislation of the national law 48/1982 but indicate the Lake being eutrophic.

Table 2. Physicochemical analysis of water samples collected from El Manzala Lake.

\begin{tabular}{|c|c|c|c|c|c|}
\hline Parameter & Unit & Minimum & Maximum & Average +SD & Permissible limits* \\
\hline Temp & ${ }^{\circ} \mathbf{C}$ & 16 & 32 & - & $<35^{\circ} \mathrm{C}$ \\
\hline pH & & 6.7 & 7.9 & - & $6.0-9.0$ \\
\hline Salinity & $\mathrm{g} / \mathrm{l}$ & 2 & 3.4 & $2.6 \pm 0.4$ & - \\
\hline DO & $\mathrm{mgO}_{2} / \mathrm{l}$ & 1.8 & 9.7 & $6.7 \pm 2.45$ & $>4$ \\
\hline COD & $\mathrm{mg} / \mathrm{l}$ & 38 & 459 & $139.4 \pm 115$ & - \\
\hline BOD & $\mathrm{mg} / \mathrm{l}$ & 25 & 306 & $92.8 \pm 76.6$ & - \\
\hline TDS & $\mathrm{g} / \mathrm{l}$ & 23.6 & 39 & $28.7 \pm 496$ & $<650$ \\
\hline $\mathrm{NH}_{4}-\mathbf{N}$ & mgN/l & 0.0 & 2.6 & $0.70 \pm 0.73$ & $<0.5$ \\
\hline $\mathrm{NO}_{2}$ & $\mathrm{mg} \mathrm{NO} / \mathrm{l}$ & 0.0 & 1.6 & $0.38 \pm 0.46$ & $<0.3$ \\
\hline $\mathrm{NO}_{3}$ & $\operatorname{mg~} \mathrm{NO}_{3} / \mathrm{l}$ & 0.0 & 1.6 & $0.38 \pm 44$ & $11.3-45$ \\
\hline TP & $\mathrm{mg} / \mathrm{l}$ & 0.1 & 0.9 & $0.40 \pm 0.26$ & 1.0 \\
\hline
\end{tabular}

*Permissible Limits of Egypt legislation of the national law 48/1982.

\subsubsection{Microbiological analysis of El Manzala lake water samples.}

The microbiological parameter values presented in Table 3, total coliform, showed higher values than the limits of the Egyptian legislation of the national law 48/1982. The 
highest values were recorded in site 1 for the total bacterial count, total coliform, fecal coliform, and Staph spp, which is an indication of high waste discharge loads into the lake water [1]. The decrease in salinity in the southern side of EL Manzala lake is one of the main factors for microbial community diversity. Overall the microbiological and chemical values are decreasing as the sampling point is further away from the source of pollution (Bahr El Baqr drain), and these results are in accordance with [24] who studied the microbial profile of Burullus lake in Egypt.

Table 3. Microbiological analysis of water samples collected from El Manzala Lake.

\begin{tabular}{|c|c|c|c|c|}
\hline Sampling site & Site 1 & Site 2 & Site 3 & Site 4 \\
\hline & $\times 10^{5}$ & $\times 10^{5}$ & $\times 10^{5}$ & $\times 10^{5}$ \\
\hline \multicolumn{5}{|c|}{ Total bacterial count (cfu/100ml) } \\
\hline Minimum & 24 & 10 & 1.2 & 0.2 \\
\hline Maximum & 820 & 380 & 90 & 60 \\
\hline Average & 500 & 190 & 40.56 & 39.6 \\
\hline \multicolumn{5}{|c|}{ Spore forming bacteria $(\mathrm{cfu} / \mathbf{1 0 0 m l})$} \\
\hline Minimum & 0.3 & 0.2 & 0.05 & 0.02 \\
\hline Maximum & 0.46 & 0.4 & 0.09 & 0.03 \\
\hline Average & 0.32 & 0.27 & 0.028 & 0.01 \\
\hline \multicolumn{5}{|c|}{ Total coliform $($ Cell/100ml) } \\
\hline Minimum & 4 & 0.3 & 0.02 & 0.02 \\
\hline Maximum & 596 & 5.9 & 0.5 & 0.5 \\
\hline Average & 265 & 2.19 & 0.24 & 0.19 \\
\hline \multicolumn{5}{|c|}{ Fecal coliform $($ Cell/100ml) } \\
\hline Minimum & 3 & 0.06 & 0.02 & 0.03 \\
\hline Maximum & 253 & 2.5 & 0.5 & 0.5 \\
\hline Average & 122 & 1.1 & 0.16 & 0.16 \\
\hline \multicolumn{5}{|c|}{ Total Staph. aureus $(\mathrm{cfu} / \mathbf{1 0 0 m l})$} \\
\hline Minimum & 3.3 & 1.5 & 0.04 & 0.02 \\
\hline Maximum & 5 & 3 & 0.71 & 0.19 \\
\hline Average & 4.1 & 2.2 & 0.3 & 0.08 \\
\hline
\end{tabular}

Regarding the occurrence of cyanobacteria in El Manzala Lake, blooms of cyanobacteria appeared in the Lake through the summer season period of the study. The relative occurrence of cyanobacteria was lower in cold seasons than in warm seasons, table 4.[25] studied the phytoplankton in the drains discharging wastewater into El- Manzala Lake and found a total of 163 phytoplankton taxa, including Chlorophyceae, Cyanophyceae, Bacillariophyceae, Euglenophyceae, Dinophyceae, Conjugatophyceae, Synurophyceae, and Xanthophyceae.

Table 4. Relative occurrence of cyanobacteria in Manzala lake.

\begin{tabular}{l|c|c|c|c|c} 
Sampling sites & Autumn & Winter & Spring & Summer & Late Summer \\
\hline Site 1 & + & + & ++ & +++ & +++ \\
\hline Site 2 & + & + & ++ & +++ & +++ \\
\hline Site3 & + & + & ++ & +++ & +++ \\
\hline Site4 & + & + & ++ & +++ & +++
\end{tabular}

\subsection{Gene expression analysis.}

Fish body temperature is influenced by their surrounding environment [26] so that temperature variation had a high impact on fish physiology, including immune system regulations [27] and fish susceptibility to different bacterial pathogens [28]. TNF- $\alpha$ gene is a pro-inflammatory cytokine that is from the essential immune genes expressed vastly before other genes in the primary stages of fish infection. Moreover, it has a crucial role in adjusting inflammations. Similar to the mammalian counterparts, there is a correlation between fish TNF- $\alpha$ gene and IL-1 gene $[29,30]$. Cytokine transcription variation (TNF- $\alpha$, IL-1) in fish 
under variable temperatures were recorded $[31,32,33]$ and also many environmental stressors [34]. In this study, the TNF and IL-1 gene expression levels were up-regulated in warm seasons (Summer, late Summer), and the lowest levels were reported in the winter season. Whereas TNF- $\alpha$ and IL- 1 gene expression in the control group were constant regardless of the season, as shown in Figures 2 and 3. Gene expression of cytokine immune genes in Nile tilapia fish was also examined by [ 35] involving TGF- $\beta 1$ (13-fold), IL-1 $\beta$ (7-fold), and TNF- $\alpha$ (14-fold) were up-regulated significantly after exposure to arsenic pollution. Buchmann et al. [36] reported that upregulation in cytokine immune genes occurred in rainbow trout fish maintained at $25{ }^{\circ} \mathrm{C}$. Also, [36] found upregulation in cytokine group for animals at $15{ }^{\circ} \mathrm{C}$ and $25{ }^{\circ} \mathrm{C}$ compared to animals at $5{ }^{\circ} \mathrm{C}$. The immune response of Nile Tilapia fish was also triggered as a result of low water quality (physicochemical and microbiological) which in turn was reflected in the fish immune system as discussed in a study conducted by [37] who found that continuous exposures of Nile Tilapia fish to polluted water in Brullus Lake have adverse effects on apoptosis-associated with damaging DNA and chromosome fragments. Also, the evaluation of the biological responses to the impact of pollution in different sites in Alexandria coast was studied by [38], and they found that DNA damage in fish collected from El Max and Bahry as these areas suffered from changes resulting from human activities; untreated industrial wastewater, domestic sewage, and agricultural runoff.

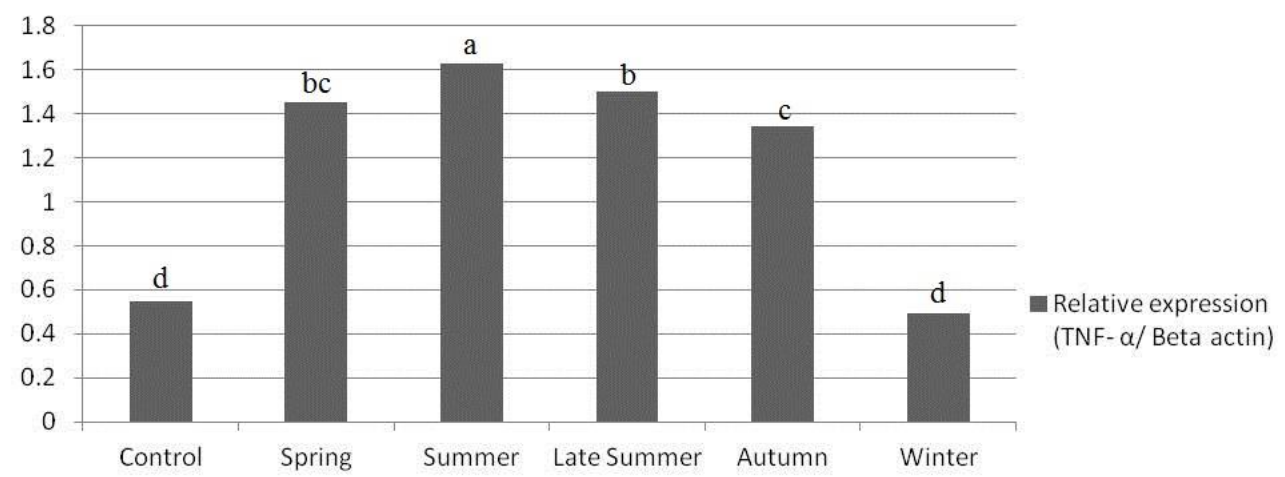

Figure 2. Quantitative analysis of the TNF - $\alpha$ levels in Nile Tilapia fish liver at different seasons. The different superscripts (a, b, c, and d) indicate significance differences ( $\mathrm{P}<0.05$, one-way ANOVA).

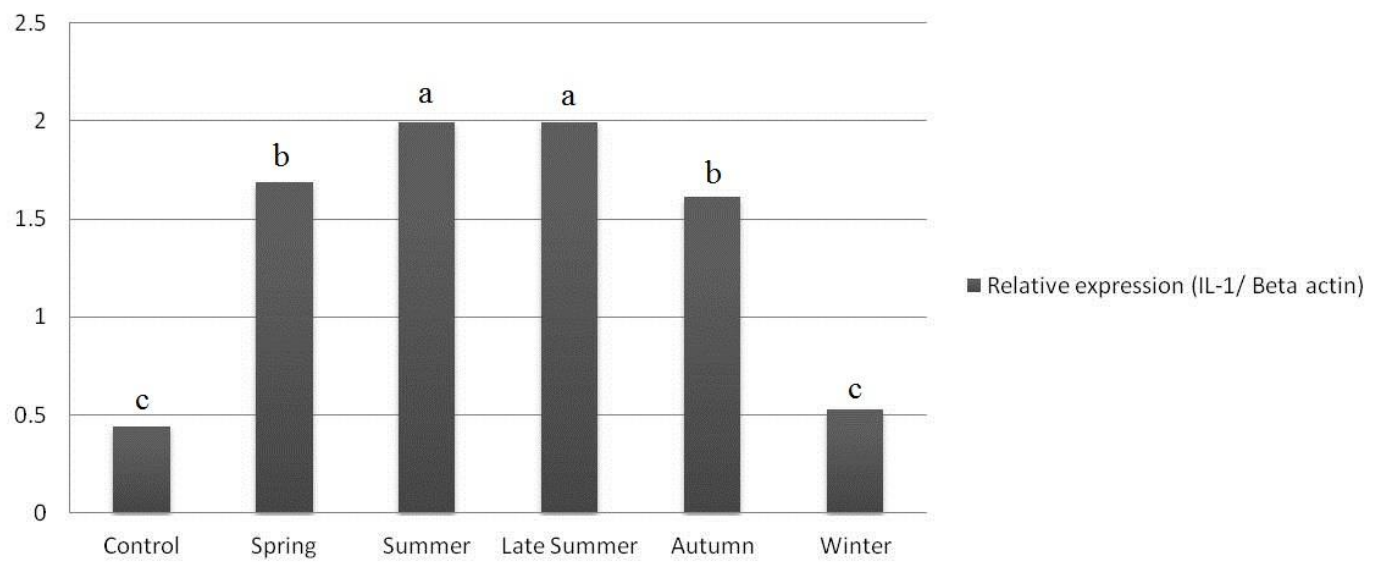

Figure 3. Quantitative analysis of the IL- 1 levels in Nile Tilapia fish liver at different seasons. The different superscripts (a, b,c and d) indicate significance differences $(\mathrm{P}<0.05$, one-way ANOVA). 


\section{Conclusions}

From the attained results, it can be suggested that many environmental factors, including temperature, may induce the alteration in the immune system of the aquatic life in El Manzala Lake. Moreover, El Manzala Lake is suffering severe problems as a result of water pollution caused by human activities, which affects not only the water physicochemical and microbiological quality but also fish where it induced tumor necrosis factor and inter Lukin gene as a result of fish bacterial infections. Thus pollution control and mitigation actions should be implemented to conserve the environment and prevent habitat degradation.

\section{Funding}

This research received no external funding.

\section{Acknowledgments}

This research has no acknowledgment.

\section{Conflicts of Interest}

The authors declare no conflict of interest.

\section{References}

1. Ismail, A. Environmental Damage Caused by Wastewater Discharge into the Lake Manzala in Egypt. American Journal of Bioscience and Bioengineering 2017, 5, https://doi.org/10.11648/j.bio.20170506.14.

2. Elmorsi, R.; Abou-El-Sherbini, K. Physicochemical properties of Manzala Lake, Egypt. Egyptian Journal of Chemistry 2017, 60, 519-535, https://doi.org/10.21608/ejchem.2017.776.1025.

3. GAFRD Annual Report of the environmental monitoring of Egyptian lakes "Lake Manzala”.General Authority for Fish Resources Development.2016.

4. Elmorsi, R. R.; Abou-El-Sherbini, K. S.; Mostafa, G. A.z; Hamed, M. A. Distribution of essential heavy metals in the aquatic ecosystem of Lake Manzala, Egypt. Heliyon, 2019, 5: e02276, https://doi.org/10.1016/j.heliyon.2019.e02276.

5. EEAAEnvironmental Impact Assessment. Central Water Quality Management. The 4th field trip report Of the Environmental Monitoring Program of Egyptian Lakes”Lake Manzala”. E. E. A. Agency.2017.

6. Abdel-Shafy, H. Water issue in Egypt: Resources, pollution and protection endeavors. Central European Journal of Medicine 2002, 8, 1-21.

7. Carfi, M.; Gennari, A.; Malerba, I.; Corsini, E.; Pallardy, M.; Pieters, R.; Loveren, H.; Vohr, H.-W.; Hartung, T.; Gribaldo, L. In vitro tests to evaluate immunotoxicity: A preliminary study. Toxicology 2007, 229, 1122, https://doi.org/10.1016/j.tox.2006.09.003.

8. Ismail, A.; Hettiarachchi, H.. Environmental Damage Caused by Wastewater Discharge into the Lake Manzala in Egypt. American Journal of Bioscience and Bioengineering. Vol. 5, No. 6, 2017, pp. 141-150. doi: 10.11648/j.bio.20170506.14

9. $\quad$ El-Mezayen, M. M.; Rueda-Roa, D. T.; Essa, M. A.; Muller-Karger, F. E.; Elghobashy, A. E. Water quality observations in the marine aquaculture complex of the Deeba Triangle, Lake Manzala, Egyptian Mediterranean coast. Environ Monit Assess. 2018, 190, 436 https://doi.org/10.1007/s10661-018-6800-6

10. Secombes, C.J.; Wang, T.; Hong, S.; Peddie, S.; Crampe, M.; Laing, K.J.; Cunningham, C.; Zou, J. Cytokines and innate immunity of fish. Developmental and comparative immunology 2001, 25, 713-723, https://doi.org/10.1016/s0145-305x(01)00032-5.

11. Salaun, B.; Romero, P.; Lebecque, S. Toll-like receptors'two-edged sword: when immunity meets apoptosis. European journal of immunology 2007, 37, 3311-3318, https://doi.org/10.1002/eji.200737744.

12. Yin, Y.W., Zhang, P.J., Yue, X.Y., Du, X.Y., Li, W., Yin, Y.L., Yi, C., Li, Y.H.,. Effect of sub-chronic exposure to lead $(\mathrm{Pb})$ and Bacillus subtilis on Carassius auratus gibelio: Bioaccumulation, antioxidant responses and immune responses. Ecotoxicol. Environ. Saf. 2018, 161: 755-762. https://doi.org/10.1016/j.ecoenv.2018.06.056.

13. Li, M.Y.; Zhu, X.M.; Tian, J.X.; Liu, M.; Qang, G.Q. Dietary flavonoids from Allium mongolicum Regel promotes growth, improves immune, antioxidant status, immunerelated signaling molecules and disease 
resistance in juvenile northern snakehead fish (Channa argus). Aquaculture 2019a. 501: 473-481. https://doi.org/10.1016/j.aquaculture.2018.12.011.

14. Li, M.Y., Liu, X.Y., Xia, C.G., Wang, G.Q., Zhang, D.M.. Astaxanthin enhances hematology, antioxidant and immunological parameters, immune-related gene expression, and disease resistance against in Channa argus. Aquac. Int. 2019b, (27): 735-746. https://doi.org/10.1007/s10499-019-00362-w.

15. APHA “APHA. 1998 Standard methods for the examination of water and wastewater. 1998, 20.

16. ISO:4833-1 Microbiology of the food chain Horizontal method for the enumeration of microorganisms.2013.

17. Vogel and Johnson. Public Health Lab. 1960, 18,131.

18. Rippka, R.; Deruelles, J.; Waterbury, J.B.; Herdman, M.; Stanier, R.Y. Generic Assignments, Strain Histories and Properties of Pure Cultures of Cyanobacteria. 1979, 111, 1-61, https://doi.org/10.1099/00221287-111-1-1.

19. Pirarat, N.; Pinpimai, K.; Endo, M.; Katagiri, T.; Ponpornpisit, A.; Chansue, N.; Maita, M. Modulation of intestinal morphology and immunity in nile tilapia (Oreochromis niloticus) by Lactobacillus rhamnosus GG. Research in Veterinary Science 2011, 91, e92-e97, https://doi.org/10.1016/j.rvsc.2011.02.014.

20. Selim, K.M.; Reda, R.M. Improvement of immunity and disease resistance in the Nile tilapia, Oreochromis niloticus, by dietary supplementation with Bacillus amyloliquefaciens. Fish \& shellfish immunology 2015, 44, 496-503, https://doi.org/10.1016/j.fsi.2015.03.004.

21. Choi, K.; Lehmann, D.W.; Harms, C.A.; Law, J.M. Acute hypoxia-reperfusion triggers immunocompromise in Nile tilapia. Journal of aquatic animal health 2007, 19, 128-140, https://doi.org/10.1577/h06-010.1.

22. Abdel-Gawad, F.; Ali; El-Shafai, S.; Samhan, F.; Khalil, W. Effect of water pollution on expression of immune response genes of Solea aegyptiaca in Lake Qarun. African Journal of Biotechnology 2008, 7, 14181425. DOI: 10.5829/idosi.wasj.2014.32.12.91175

23. Chen, J.H., Ren, Y.C., Li, Y.Q., Xia, B. Regulation of growth, intestinal microbiota, non-specific immune response and disease resistance of sea cucumber, Apostichopus japonicus selenka in biofloc systems. Fish Shellfish Immunol. 2018, 77, 175-186, https://doi.org/10.1016/j.fsi.2018.03.053.

24. Mousa, I.E.; Emara, I.K.; Farfour, S.A.; Eldourghamy, A.S.J.W.; journal, e. Microbial profile and its changing rates of $\mathrm{L}$ ake $\mathrm{B}$ urullus, $\mathrm{E}$ gypt as wastewater receiving body. 2018, 32, 67-74. https://doi.org/10.1111/wej.12292.

25. Monem, A.M.A.; Gharieb, M.M.; Hussian, A.-E.M.; Flefil, N.S. Sensitivity of Phytolankton to the Wastewater Quality Discharging at Lake Manzala, Egypt. International Journal of Oceans and Oceanography 2017, 11, 231-247.

26. Fry, F.J.J.T. Responses of vertebrate poikilotherms to temperature.Thermobiology 1967, 375-409.

27. Baudouy, A.; Danton, M.; Merle, G. Experimental infection of susceptible carp fingerlings with spring viremia of carp virus, under wintering environmental conditions. In: Fish Diseases. Springer: 1980; pp. 2327.

28. Karvonen, A.; Rintamäki, P.; Jokela, J.; Valtonen, E.T. Increasing water temperature and disease risks in aquatic systems: Climate change increases the risk of some, but not all, diseases. International Journal for Parasitology 2010, 40, 1483-1488, https://doi.org/10.1016/j.ijpara.2010.04.015.

29. Zhang, A.; Chen, D.; Wei, H.; Du, L.; Zhao, T.; Wang, X.; Zhou, H. Functional characterization of TNF- $\alpha$

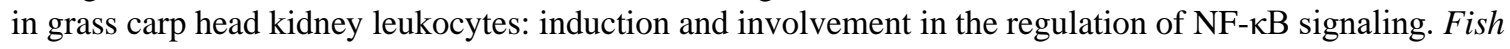
\& shellfish immunology 2012, 33, 1123-1132, https://doi.org/10.1016/j.fsi.2012.08.029.

30. Eggest $\varnothing 1$, H.; Lunde, H.S.; Haugland, G. T. The pro-inflammatory cytokines TNF- $\alpha$ and IL-6 in lumpfish (Cyclopterus lumpus L.) -identification, molecular characterization, phylogeny and gene expression analyses. Developmental \& Comparative Immunology 2020, 105, 103608, https://doi.org/10.1016/j.dci.2020.103608.

31. Feder, M.E.; Hofmann, G.E. Heat-shock proteins, molecular chaperones, and the stress response: evolutionary and ecological physiology. Annual review of physiology 1999, 61, 243-282, https://doi.org/10.1146/annurev.physiol.61.1.243.

32. Pérez-Casanova, J.C.; Rise, M.L.; Dixon, B.; Afonso, L.O.B.; Hall, J.R.; Johnson, S.C.; Gamperl, A.K. The immune and stress responses of Atlantic cod to long-term increases in water temperature. Fish \& shellfish immunology 2008, 24, 600-609, https://doi.org/10.1016/j.fsi.2008.01.012.

33. Kayansamruaj, P.; Pirarat, N.; Hirono, I.; Rodkhum, C. Increasing of temperature induces pathogenicity of Streptococcus agalactiae and the up-regulation of inflammatory related genes in infected Nile tilapia (Oreochromis niloticus). Veterinary Microbiology 2014, 172, 265-271, https://doi.org/10.1016/j.vetmic.2014.04.013.

34. Zhia, T.; Xua, X.; Chena, J.; Zhenga, Y.; Zhanga, S.; Penga, J.; Brownb, C. L. and Yang, T. Expression of immune-related genes of Nile tilapia Oreochromis niloticus after Gyrodactylus cichlidarum and Cichlidogyrus sclerosus infections demonstrating immunosupression in coinfection. Fish \& Shellfish Immunology 2018, 80, 397-404, https://doi.org/10.1016/j.fsi.2018.05.060.

35. Zahran, E.; Awadin, W.; Risha, E., Khaled, A. A.; Wang, Tiehui. Dietary supplementation of Chlorella vulgaris ameliorates chronic sodium arsenite toxicity in Nile tilapia Oreochromis niloticus as revealed by histopathological, biochemical and immune gene expression analysis. Fisheries Science 2019, 85, 199-215, https://doi.org/10.1007/s12562-018-1274-6. 
36. Bowden, T.J.; Thompson, K.D.; Morgan, A.L.; Gratacap, R.M.L.; Nikoskelainen, S. Seasonal variation and the immune response: A fish perspective. Fish \& shellfish immunology 2007, 22, 695-706, https://doi.org/10.1016/j.fsi.2006.08.016.

37. El Nahas, A.F.; Abdel-Razek, M.A.S.; Helmy, N.M.; Mahmoud, S.; Ghazy, H.A. Impaired antioxidant gene expression by pesticide residues and its relation with other cellular biomarkers in Nile Tilapia (Oreochromis niloticus) from Lake Burullus. Ecotoxicology and Environmental Safety 2017, 137, 202-209, https://doi.org/10.1016/j.ecoenv.2016.12.006.

38. Guerriero, G.; Bassem, S.M.; Abdel-Gawad, F.K.J.E.J.o.F.; Agriculture. Biological responses of white sea bream (Diplodus sargus, Linnaeus 1758) and sardine (Sardine pilchardus, Walbaum 1792) exposed to heavy metal contaminated water.Emirates Journal of Food and Agriculture, 2018, 688694, https://doi.org/10.9755/ejfa.2018.v30.i8.1762. 